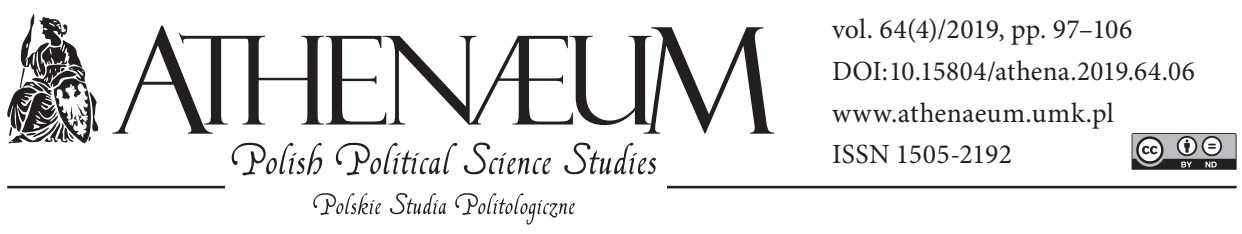

\title{
THE USE OF FREEDOM OF ARTISTIC EXPRESSION IN THE CONTEXT OF THE NECESSITY OF RESPECTING HUMAN RIGHTS (THE POLISH PERSPECTIVE)
}

\author{
KORZYSTANIE Z WOLNOŚCI WYPOWIEDZI ARTYSTYCZNEJ \\ W KONTEKŚCIE KONIECZNOŚCI POSZANOWANIA PRAW \\ CZŁOWIEKA (POLSKA PERSPEKTYWA)
}

Kinga Machowicz* $\odot$

\begin{abstract}
- ABSTRACT
Works of art often refer to privacy or the freedom of conscience and religion. The goal of the study is to contribute to the discussion on resolving conflict situations arising from the way of reception of art and to point out circumstances worth taking into consideration while choosing measures intended to prevent conflicts or at least minimize the effects of conflict situations that have already occurred. That is why it appears indispensable to consider difficulties in defining art-related concepts basing on social science, and to present artistic creation as a form of expression, as well as to analyze the determinants of the freedom of artistic creation as a law-protected interest in the political-legal system in the situation of conflict with other human rights.
\end{abstract}

Keywords: human rights; freedom of expression
Dzieła sztuki często nawiązują do prywatności lub wolności sumienia i religii. Celem opracowania jest przyczynienie się do rozwoju dyskusji na temat rozwiązywania konfliktowych sytuacji wynikających ze sposobu odbioru sztuki oraz wskazanie okoliczności wartych uwzględnienia podczas wyboru działań mających zapobiegać konfliktom lub przynajmniej minimalizować skutki już zaistniałych sytuacji konfliktowych. Dlatego jako niezbędne jawi się rozważenie trudności w definiowaniu na gruncie nauk społecznych pojęć związanych ze sztuką oraz przedstawienie twórczości artystycznej jako formy wypowiedzi, a także przeprowadzenie analizy uwarunkowań wolności twórczości artystycznej jako dobra chronionego w systemie polityczno-prawnym w sytuacji konfliktu z innymi prawami człowieka.

Słowa kluczowe: prawa człowieka; wolność wypowiedzi

\footnotetext{
* The John Paul II Catholic University of Lublin, Faculty of Social Sciences.
} 


\section{INTRODUCTION}

Freedom of expression is one of personal human rights, and one of the forms of expression is artistic expression or art. Significantly, the concept of art or even the work of art is not defined in the legislation. In contrast, there is rich literature on the conflict between the freedom of expression and other human rights. With regard to analyzing the position of the protection of one form of expression, i.e. artistic creation, in the spectrum of human rights protection, one may however feel still unsatisfied to some extent. On the one hand, art is covered by guarantees provided for freedom of expression, whereas on the other hand, while interacting with other human rights, it may violate the rights of other individuals.

Furthermore, it appears that artistic creativity may, in a highly spectacular way, interact in conflict particularly with the right to private life and the freedom of conscience and religion. That is why the goal of this study is to contribute to the development of discussion on resolving conflict situations arising from the ways of receiving works of art referring to a person's privacy or to phenomena being part of the realization of the freedom of conscience and religion, as well as to show circumstances worth taking into consideration while choosing measures intended to prevent conflicts or at least minimize the effects of conflict situations that have already occurred. The article was written by the descriptive method, interpretation of legal acts, and critical analysis of literature, including judicial decisions. Although judicial decisions do not have the quality of the sources of generally applicable law, they come from the established uniform jurisprudential line and for that reason they can be a significant support in interpreting legal norms.

The Level of A Scientific Discipline and Definability of Art-Related Concepts

Art or artistic creation is concepts that are utilized by different disciplines. At the same time, these terms are not, by assumption, easy to define. We may even wonder if at all and, possibly, to what extent, it is necessary to define them. For there is quite a large number of concepts that legislation does not specifically define but leaves their meanings assigned by natural language. Contracts for specific works have been regulated by law and the concept of work has been defined. Even though these definitions make it possible to provide legal protection, they are unable to convey the essence of the specificity of art as a social phenomenon. Political and legal sciences face the same challenge: "In the humanities and in social science it is far more difficult to establish indisputable truths than in exact science, natural science, medical science or technical science. Social processes 
are far less verifiable objects of research, they are more diversified, more ambiguous than the objects of inquiries by mathematicians, physicists, or engineers" (Sobczak, 2008, p. 58). The definition of art given below is one of many, but is a quintessence of the elements discussed in literature: "Art is a re-creation of things or construction of forms or expression of experiences - if the product of this re-creation, construction, expression is able to enrapture, or move, or shock" (Tatarkiewicz, 1988, p. 52). For years, the conceptions of what the author of a work of art is, and what the creation process actually consists in, have changed (Wilkowski, 2014). Therefore art, as activity consisting in imparting a view or an idea and intended to produce a reaction to this communication is a form of expression. This observation stems both from the ways of defining art and from the distinct wording of legal provisions at different levels.

When defining the objectively significant elements of a specific work contract, the legislator has decided that its inherent element is remuneration. There are different motivations for, ways and currency of remuneration for creative activity (Wilkowski, 2015). However, the fact of not receiving remuneration is not an element that excludes some phenomenon from the sphere of art. Polish language knows the expression: 'create for the drawer' [create for one's own pleasure or without a chance/hope for publication]. The author thus assumes that $\mathrm{s} / \mathrm{he}$ will not reveal his/her creative output for some time, thereby depriving him/herself of the possibility of obtaining remuneration for the use of his/her work. A shocking example pointed out in literature is the creative activity of concentration camp prisoners, who turned precisely to artistic creation as the most personal form of objection towards inhuman treatment (Bieczyński, 2011).

In respect of artistic expression, the inquiries of social sciences primarily focus, however, on the issues connected with the commission of insult to religious feelings, plagiarism, forgery of works of art or dissemination of pornography, and on the questions of labor law and social security with regard to persons who earn remuneration from their creative work, as well as on the issues of violation of personal interests such as dignity (reputation, renown) or image (usually in relation to politicians in the context of satirical or caricaturing expression as the disapproval of their public behavior). 


\section{ARTISTIC CREATION AS A FORM OF EXPRESSION}

One of the forms of artistic creation (and thereby one of the forms of expression) is so-called artistic provocation. Provocation means to challenge someone, to deliberately taunt them, insidiously incite, or instigate someone to take actions or decisions detrimental to them (or to a third party) (Kopaliński, 1972). At present, it is regarded as an admittedly controversial (due to its shocking, explicit character) but nevertheless as one of means of artistic expression. By assumption, the goals of art should draw on the first of the dictionary meanings: to challenge or deliberately taunt in the sense of putting sufficient pressure on the receivers so that, at least in a given moment, they will focus their interest on the phenomenon indicated by the artist. If this is not the case, then we can assume that we are not dealing with art but with pseudo-artistic activities that are not accorded legal protection.

Other forms of artistic creation include satire. It is assumed that if, with satirical convention in mind, it is possible to ridicule a person; it is, however, inadmissible to present them in a manner that leads to reviling and showing contempt for them in an extreme way (Tymiec, 2006). Nevertheless, despite appearances, there is also a positive program in satire, but it is generally well concealed. It is rather the receiver of a satirical work who, by themselves as it were, are expected, by accepting the satirical author's negative assessments as their own, to arrive at the conclusions approved albeit not directly formulated by the satirist. It is on this that the power of satire is based, and it is where its danger lies with regard to individuals and groups who become the butt of satirical comment, not to say attack. That is why satirical works are so readily received by the society and so fiercely fought against by those who have been stung by satire (Sobczak, 2016). A caricature is, however, a humorous, derisive emphasis on and exaggeration of characteristic features of a person, a thing or events, mainly in fine arts and literature (Kopaliński, 1972).

\section{FREEDOM OF ARTISTIC CREATION AS A LAW-PROTECTED INTEREST IN THE POLITICAL-LEGAL SYSTEM}

The political system of the Republic of Poland is based on the principle of a democratic state ruled by law, from which follows the state's obligation to respect human rights. However, only few of them are absolute. Rights that may conflict with other law-protected interests in the political-legal system (includ- 
ing the human rights of other individuals) may be restricted. Furthermore, the legislature assumed the possibility of introducing restrictions without a priori granting precedence to other rights that they value highly. Each time, the situation requires an individual settlement in the circumstances of a specific conflict. A constitutional principle (Article 14) is also to ensure freedom of the press and other means of social communication.

Article 31 of the Constitution provides for the limitations of human rights (including freedom of expression). It permits the imposition of limitations on the whole category of human rights, which are not absolute rights. Norms that guarantee the protection of particular rights have to be interpreted in conjunction with this provision. Everyone is thus obliged to respect the freedoms and rights of others. Restrictions upon the exercise of constitutional freedoms and rights may be imposed only by statute and only when they are necessary in a democratic state, inter alia, to protect public morals or the freedoms and rights of other persons. Such limitations may not, however, violate the essence of freedoms and rights.

Under Article 54 of the Constitution, the freedom to express opinions, to acquire and disseminate information is ensured to everyone. Article 73 of the Constitution stipulates that the freedom of artistic creation, scientific research, and dissemination of their results, the freedom to teach as well as enjoy the products of culture shall be ensured to everyone. The combination in Article 73 of the foregoing five freedoms can be justified by their shared feature, which is creative activity (Jabłoński, 2002). A common feature of any creative activity is to satisfy the factors of creativity, originality and independence (Szewc, 1997). Article 10 of the Convention for the Protection of Human Rights and Fundamental Freedoms in turn guarantees everyone the right to freedom of expression. This right includes freedom to hold opinions and to receive and impart information and ideas. The exercise of these freedoms, carrying with it duties and responsibilities, may be subject to such formalities, conditions, restrictions or penalties as are prescribed by law and necessary in a democratic society, inter alia, for the protection of morals, for the protection of the reputation and rights of others. Under Article 11 of the Charter of Fundamental Rights of the European Union, everyone has the right to freedom of expression. This right includes freedom to hold opinions and to receive and impart information and ideas without interference by public authority and regardless of frontiers.

Under Article 19 of the International Covenant on Civil and Political Rights, every person has the right to hold opinions without interference. Everyone has 
the right to freedom of expression; this right includes freedom to seek, receive and impart information and ideas of all kinds, regardless of frontiers, either orally, in writing or in print, in the form of art, or through any other media of his/her choice. The exercise of these rights carries with it special duties and responsibilities. It may therefore be subject to certain restrictions, which should, however, be explicitly provided by law and are necessary:

a) for respect of the rights or reputations of others;

b) for the protection of national security or of public order, or of public health or morals.

Interference with human rights cannot be unlawful or arbitrary.

\section{ARTISTIC CREATION AS A POTENTIALLY PRIVILEGED EXPRESSION IN THE SITUATION OF CONFLICT WITH OTHER INTERESTS PROTECTED BY LAW}

It is often assumed that, on account of its uniqueness or social function, art is so exceptional a phenomenon that it is not subject to generally accepted social norms, particularly legal ones. "This understanding of a creative act, placing it beyond the scope of conceptual cognition and ethics, gained popularity throughout the nineteenth century. The figure of genius - continually evoked by criticalartistic discourse, estheticians, and by artists themselves - deeply influenced the perception of the artist's social role in Western culture (Białkowski, 2010). In contrast, court practices adopt an entirely different point of view: "The artistic form or scientific objective of an insulting act do not by themselves exclude criminal responsibility for insult to religious feelings or for public insult to an object of religious worship" (Decision of the Supreme Court..., 2015). The cited fragment is only one of the excerpts from the uniform line of judicial decisions. It confirms the abandoning of the conception of art as a phenomenon free from any limitations. This conception was particularly advocated by artists themselves. "Kant separated ethical from esthetic categories. He was the first to prove that good and beauty do not need to go hand in hand, that they are independent of each other [...]. From this, artists drew conclusions to their advantage: total freedom of morals, and rights to moral opposition [...]. What used to be the play of Dada artists and surrealists in 1920 became a socially dangerous movement of confounded young people mooning about the world's roads and towns fifty years later. What conclusion can be inferred from this? A strange one but not without 
reason: although ethical laws do not influence the value of a work of art, yet art as a social phenomenon, as a communication of ideas, has to respect ethical laws because otherwise it turns harmful, and artists have the same moral obligations like all others" (Estreicher, 1990). At the same time, it is an offence to publicly display pornographic material in such a manner that it may be imposed upon a person against their wish (Article 202 of the Criminal Code). The content of the norm is in accordance with the limitations on human rights provided for in international law because it takes into account the necessity of protecting public morals, but literature emphasizes that the systematic broadening of the content of Article 202 (Criminal Code) should be seen as a threat to the freedom of artistic expression. The motifs of human nudity, human sex life and accompanying feelings have been present in art for centuries. Broad freedom should be accorded to creative activity except for the rationally specified protection of minors against presentation of pornographic materials. The argument in favor of this reasoning is the absence of criminal intent on the part of the artist. Each case should obviously be examined ad casum, taking into account other factors essential to its actuality (Źarnowska-Grabarz, 2017).

On the other hand, with regard to other sensitive issues, the need to use extreme media of artistic communication is called into question. "It is highly debatable, however, whether the opinions by an artist in a discussion on such important issues as antisemitism, crisis of religious values or homophobia need to be expressed by means of artistic expression operating on the edge of the law" (Gienas, 2010, p. 8). It is conceded that Strasburg's judicial decisions based on the question of freedom of expression clearly distinguished between artistic expression and other forms of expression, making the extent of the accorded protection conditional upon the results of assessment: "However, in cases of 'pure' (non-political) artistic expression, censored to meet religious or moral objections from a section of society, the [European] Court [of Human Rights] accords much less protection. Whether speech is classified as 'political' or 'non-political' is therefore crucial when the Court assesses the legitimacy of an interference with free expression" (Lester, 2014, p. 76).

The protection of political speech is usually linked with journalism practiced in accordance with the rules of this profession: "New Journalism is serious journalism, treating their audience and subject seriously, practiced by serious journalist conscious of the goals and techniques of their work. Equivalents of this kind of journalism can be the categories of quality, involvement, opinionforming, neutrality, localness, and good citizenship" (Hofman, 2016). In the 
judicial decisions of the ECHR, this kind of journalism is therefore more likely to be accorded protection than artistic expression.

It follows from the presented arguments that freedom of expression is interpreted in legal regulations not as absolute freedom but as one of human rights that may be restricted under specific circumstances. Furthermore, international obligations indicate that it is responsible expression that is protected. Artistic creation is one of many forms of expression; consequently, it may be restricted under the same terms as the other forms. There are therefore no legal grounds for treating artistic communication in an especially privileged way.

\section{CONCLUSIONS}

In the case of conflict between freedom of expression (including artistic creation) and other human rights, there is no model solution that would a priori give priority to freedom of expression or to the other rights. The situation of a particular conflict always has to be assessed in relation to specific circumstances. In accordance with the established, repeatedly confirmed decisions of the European Court of Human Rights, the state is less able to interfere in the freedom of expression in the case of more or less closed events (e.g., those by-tickets-only). In Poland, this mode of action is suggested by the judicial decisions made in recent years in cases which provoked public debate on the restrictions on artistic expression. It was the acquittal of artist Dorota Nieznalska charged with offending religious feelings through the controversial installation "Passion [Pasja]" and the acquittal of singer Adam Darski accused of offending religious feelings through the act of tearing up the pages of a Bible during a concert, whose visual and sound recording was prohibited. In contrast, singer Dorota Rabczewska was validly found guilty of offending religious feelings when, during an interview, she said that the Bible had been written by pot-smoking men drunk with wine.

Taking account of the essence of the phenomenon which is art and of general situational determinants, it can be expected that the conflicts in question cannot be avoided. What is left is to relieve tensions. An element conducive to easing conflicts is complex (rather than fragmentary) education on human rights. Such education should clearly show that the exercise of one's own rights also involves one's obligations. In turn, resolving arisen conflicts should take into account the European standards developed in judicial decisions since there are situations when the state enjoys a wide margin of assessment. They apply to freedom of 
thought, conscience and religion because in Europe there is no uniform view on the social role and importance of religion. Freedom of religious beliefs is at the same time one of the most important elements determining the identity of believers and the conception of their life. That is why the national authorities, when undertaking inference serving to protect the rights of believers, retain a significant freedom of assessment, like in the case of restrictions intended to protect morals. A national judge is in a better position than the international court when trying to identify and assess the needs existing in a given country (Kamiński, 2003).

Shocking means of artistic expression cannot be justified only by the need to promote the artist's name. The general principle should be also applied of achieving the intended goal by using sufficient means but, at the same time, as little shocking as possible. Economy in the use of too drastic means of expression may also serve to preserve art as a form of expression that genuinely influences the audience, thereby contributing to enriching freedom of expression as a human right. The excessive use of stimuli may blunt the perception of the receivers, and, consequently, limit the possibility of reception of artistic communication. The public are often simply tired of too many stimuli. The existence of such risk is at least indirectly evidenced by widely-received works created using minimalist means of expression.

\section{REFERENCES:}

Charter of Fundamental Rights of the European Union, Signed Again in 2007 in Lisbon. Consolidated text: Official Journal of the EU of 7 June 2016, C 202, 389-405.

Constitution of the Republic of Poland of 2 April 1997, Dz.U. [Journal of Laws] No. 78, item 483 as amended.

Convention for the Protection of Human Rights and Fundamental Freedoms of 4 November 1950. Polish Text: Dz.U. [Journal of Laws] of 1993 No. 61, item 284 as amended.

Bieczyński, M.M. (2011). Prawne granice wolności twórczości artystycznej w zakresie sztuk wizualnych. Warszawa: Wolters Kluwer - LEX.

Białkowski, Ł. (2010). Człowiek pogryzł psa. Uwagi o „wolności twórczej” jako konsekwencji Kantowskiej figury geniusza. Episteme, 1(10), 139-152.

Decision of the Supreme Court of 5 March 2015. II KK 274/14, “OSNKW" 2015, 9(72).

Estreicher, K. (1990). Historia sztuki w zarysie. Warszawa-Kraków: PWN.

Gienas, K. (2010). Kontrowersyjność sztuki jako problem prawa autorskiego. Zeszyty Naukowe Uniwersytetu Jagiellońskiego. Prace z prawa własności intelektualnej, 2(2), 5-19. 
Hofman, I. (2016). Nowe Dziennikarstwo. Próba rekonstrukcji modelu. Athenaeum. Polskie Studia Politologiczne, 49, 67-77. DOI: 10.15804/athena.2016.49.04.

Jabłoński, M. (2002). Wolności z art. 73 Konstytucji RP. In: B. Banaszak, \& A. Preisner (eds.). Prawa $i$ wolności obywatelskie w Konstytucji RP (pp. 551-568). Warszawa: C.H. Beck.

Kamiński, I.C. (2003). Swoboda wypowiedzi w orzeczeniach Europejskiego Trybunału Praw Człowieka w Strasburgu. Kraków: Kantor Wydawniczy Zakamycze.

Kopaliński, W. (1972). Słownik wyrazów obcych i zwrotów obcojęzycznych. Warszawa: Wiedza Powszechna.

Lester, A. (2014). Sztuka dla sztuki - komentarz do orzecznictwa Europejskiego Trybunału Praw Człowieka w sprawach z zakresu wolności wypowiedzi artystycznej. In: D. Bychawska-Siniarska, \& D. Głowacka (eds.). Swoboda wypowiedzi w działalności artystycznej (pp. 76-83). Warszawa: Helsińska Fundacja Praw Człowieka.

Sobczak, J. (2008). Polityka historyczna a wolność ekspresji, twórczości artystycznej i badań naukowych. In: M. Kosman (ed.). Na obrzeżach polityki. Część szósta (pp. 49-61). Poznań: Wydawnictwo Naukowe WNPiD UAM.

Sobczak, J. (2016). Wolność ekspresji artystycznej. Regulacje europejskie a rozwiązania polskiego systemu prawnego. Czasopismo Prawno-Historyczne, 68(2), 237-293. DOI: $10.14746 / \mathrm{cph} .2016 .69 .2 .15$.

Szewc, A. (1997). Dzieła naukowe i ich status w prawie autorskim. Państwo i Prawo, $52(10), 23-31$.

Tatarkiewicz, W. (1988). Dzieje sześciu pojęć. Warszawa: PWN.

Tymiec, R. (2006). Satyra a ochrona czci w polskim prawie cywilnym. In: M. Warciński, \& K. Zaradkiewicz (eds.). Wybrane zagadnienia prawa cywilnego (pp. 311-370). Warszawa: C.H. Beck.

Wilkowski, M. (2015). Historia wynagradzania twórczości. Warszawa: Fundacja Nowoczesna Polska. Retrieved from: https://prawokultury.pl/media/entry/attach/ MarcinWilkowski_Historia_wynagradzania_tworczosci.pdf.

Żarnowska-Grabarz, P. (2017). Pornografia w sztuce a odpowiedzialność karna artystów - uwagi na tle art. 202 kodeksu karnego. Palestra, 7-8, 62-69. 